\title{
Promoting sustainability through brownfields redevelopment in Caguas, Puerto Rico
}

\author{
J. Vélez-Arocho ${ }^{1}$, R. Torres ${ }^{2}$, S. M. Veláquez-Rivera ${ }^{3}$ \\ \& G. Rivera ${ }^{3}$ \\ ${ }^{1}$ Ecostahlia Consultores Ambientales, USA \\ ${ }^{2}$ United States Environmental Protection Agency, USA \\ ${ }^{3}$ Autonomous Municipality of Caguas, USA
}

\begin{abstract}
Serious industrial, economic, and tax-related transformations have left the archipelago of Puerto Rico with a vast number of vacant, abandoned, and idle properties resulting on a series of environmental, social, legal, and economic issues in several communities. Performing environmental assessments on these properties have proven to be a key factor to assist in the removal of these issues, allowing the possibility for redevelopment and revitalization of the impacted communities. Over the past years, the Autonomous Municipality of Caguas (AMC) along with the United States Environmental Protection Agency (EPA) has developed many policy innovations and financial incentives to aid in environmental assessments, remediation, and redevelopment of these properties. Located in Central Puerto Rico, and with a population of 142,893 inhabitants, according to Puerto Rico: 2010 census, this municipality has experienced rapid population and urban growth during the last decade, making it difficult for the local government to provide adequate services to all its residents. In Puerto Rico approximately $41.5 \%$ of the families live below poverty level, and the unemployment rate is $11.9 \%$. For the AMC, $37.3 \%$ of the families live below poverty level and the unemployment rate is $9.8 \%$. In 2009, the AMC received $\$ 400,000$ through two brownfields grants from the EPA to perform environmental assessments on brownfield properties, related to hazardous substances and petroleum derivate. Between the two phases of the Brownfields Program, the AMC identified over 40 potential brownfield properties, such as abandoned industries, retail shops, restaurants and commercial buildings, from which 14 were assessed using a metric and a special scoring methodology (using ARCADIS
\end{abstract}


B.A.S.E. Methodology for Brownfields). The AMC conducted a Phase I Environmental Assessment to ten properties. The results of each assessment were presented to the community to allow the opportunity for valuable feedback. In the first phase of the Brownfields Program, after Phase I ESAs was conducted and no further evidence of contamination was found, three properties began procedures for sale and redevelopment. The investment from the private sector exceeded $\$ 1,200,000.00$. The AMC is committed to promote redevelopment of brownfield properties and to help funding the environmental remediation efforts to support redevelopment.

Keywords: sustainability, brownfields redevelopment, USEPA, economic development, Municipality of Caguas, community involvement, idle properties, environmental assessments, public health, business.

\section{Introduction}

EPA started 22 years ago an innovative program that has provided hundreds of communities in the United States and its territories the opportunity to develop economic activities through the use of idle commercial and industrial properties known as brownfields. A key element in reaching the goals and objectives established by the agency is the proactive community involvement and participation in all the phases of the revitalization process. The main goal of this initiative is to foster economic development while protecting public health and the environment. There are thousands of abandoned or idle commercial and industrial properties around the United States and its territories that present a real threat to cities and municipal administrators due to the potential presence of pollutants. The existence of pollutants may present a challenge for redevelopment activities. EPA's Brownfields Program is dedicated to empower states, territories, communities and other stakeholders in economic redevelopment to work together in a timely manner to prevent, assess, safely cleanup, and sustainably reuse idle properties. Brownfields Assessments Grants provide the economic incentive to perform environmental assessments to suspected contaminated sites to foster economic development and to return previously contaminated and underutilized, warehouses or abandoned properties back to productive use in favor of the environment, communities and business interests [3, 4].

In 2009, the AMC received $\$ 400,000$ through two brownfields grants from the EPA to perform environmental assessments on brownfield properties, related to hazardous substances and petroleum derivate. Between the two phases of the Brownfields Program, the AMC identified over 40 potential properties, such as abandoned industries, retail shops, restaurants and commercial buildings, from which fourteen were assessed using a metric and a special scoring methodology. The AMC conducted a Phase I Environmental Assessment to ten properties. The results of each assessment were presented to the community to allow the opportunity for valuable feedback. 


\section{An overview of the brownfields properties in Caguas, Puerto Rico}

The AMC is located in an area of 59 square miles in a central valley surrounded by mountains, also known as the Turabo Valley. Since the 1960s, the city has experienced rapid population and urban growth establishing itself as the economic center of the region. It borders on the north with San Juan and Trujillo Alto; on the east with Gurabo and San Lorenzo; on the west with Aguas Buenas, Cidra, and Cayey, and on the south with Cayey and San Lorenzo. Caguas is located 20 minutes from San Juan and one and a half hour from Ponce.

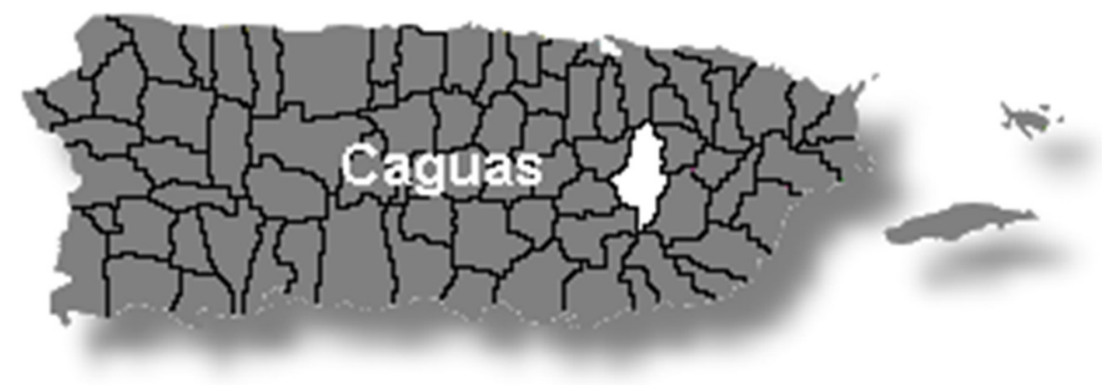

Figure 1: Municipality of Caguas general location map.

The rapid urban growth within the San Juan Metropolitan Area has created a scarcity of land in the cities, forcing residents to look for properties in the fringes of the region. According to the U.S. Census, the population in Caguas grew from 65,098 in 1960 to 140,502 inhabitants in 2000 with a population density of 2,400 inhabitants per square mile. This population expansion has presented a great challenge to the local government to provide adequate services to its residents [5].

Like in many cities and small municipalities in the Archipelago of Puerto Rico the identification, assessment and redevelopment of idle or abandoned commercial and industrial properties is a real challenge to the local and state administrators. Idle buildings are distributed around the city and the impacts to the neighborhoods are clearly visible. These abandoned or idle properties limit much needed local economic development by limiting the creation of jobs and generation of tax revenues. As part of the Brownfields Program, municipal staffers identified over 40 commercial and industrial properties and the majority of them were located within the urban center. Fourteen properties were classified as brownfield properties and only ten were performed Phase I ESAs, using a metric and a special scoring methodology developed by the contractor. 


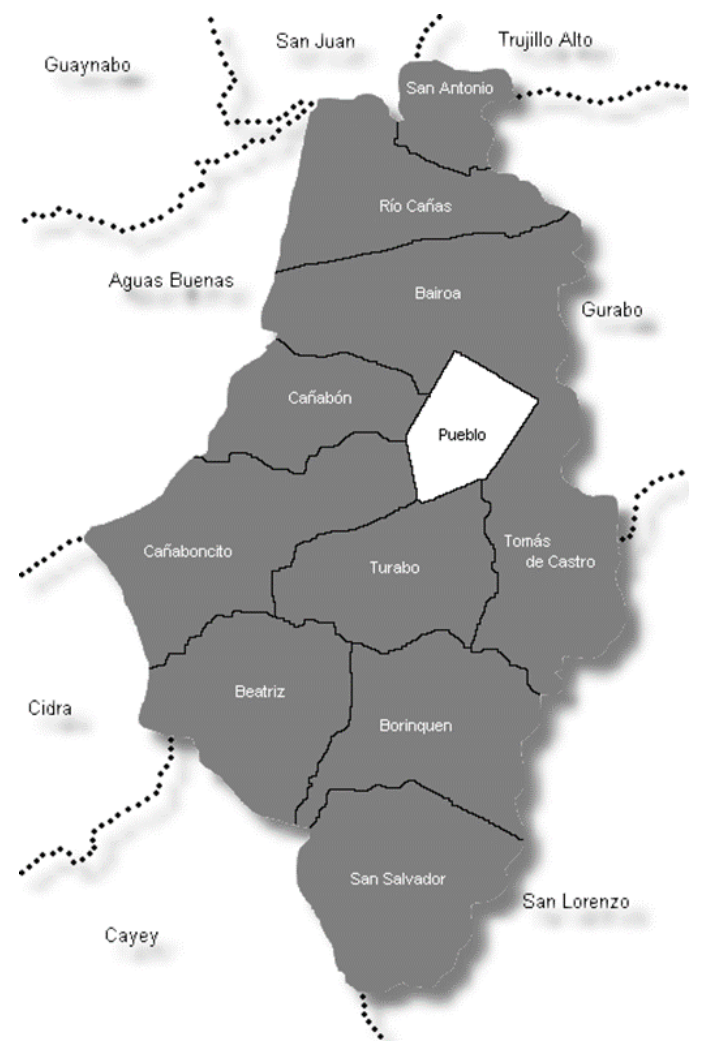

Figure 2: Municipality of Caguas and its wards.

\section{The socio-economics of Caguas and the Brownfields Program in Caguas}

Like many municipalities around Puerto Rico, many of the brownfield properties are located in areas where the economic development is limited, and the residents suffer low educational achievements. These communities also show high poverty, unemployment, and emigration rates, with a substantial reduction on the youth populations. Recent studies show that residents of the communities suffer a variety of health problems, possibly attributed to contaminated soil, air, and water from nearby brownfields [6]. The AMC has experienced the same problems identified in neighborhoods throughout the island. Located in central Puerto Rico, and with a population of 140,502 inhabitants, this municipality has experienced rapid population and urban growth during the last decade, making it difficult for the local government to provide adequate services to all its residents. In Puerto Rico, approximately $41.5 \%$ of the families live below poverty level, and the unemployment rate is $11.9 \%$. For the AMC, $37.3 \%$ of the families live below poverty level and the unemployment rate is $9.8 \%$ (Census 2010 [1]). 


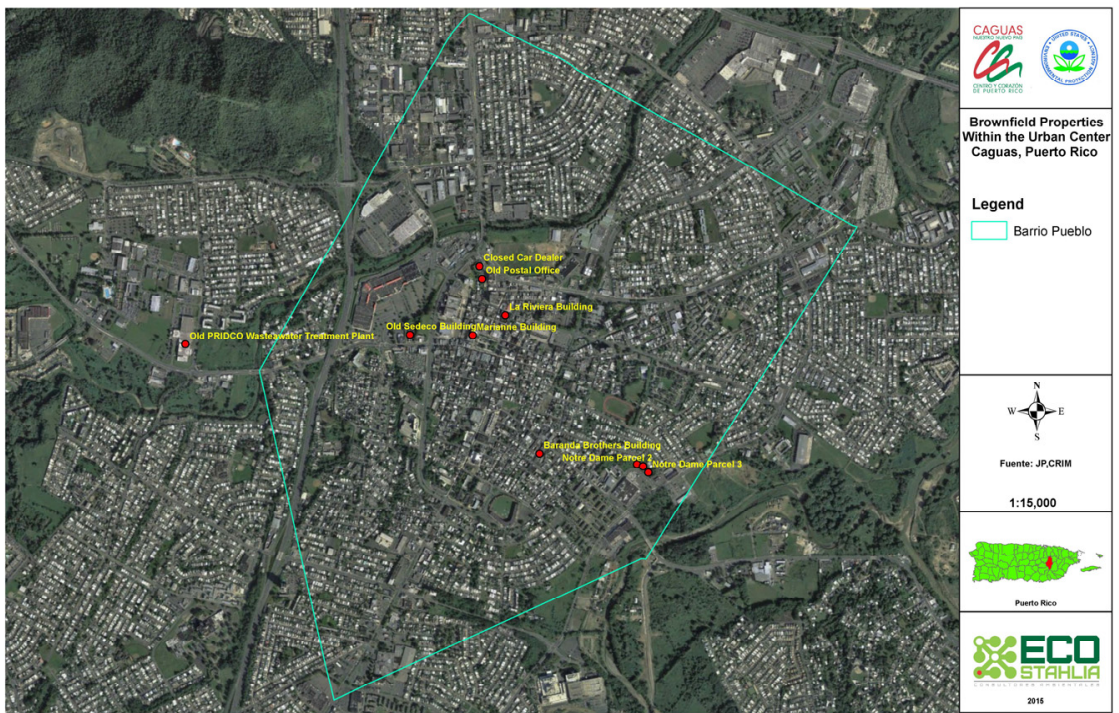

Figure 3: Distribution of brownfields properties in Caguas, Puerto Rico.

Table 1: Socioeconomic indicators and geographic comparison*.

\section{Caguas Puerto Rico}

\section{Economic}

Percent below poverty

$\begin{array}{ll}37.3 & 41.5 \\ 9.8 & 11.9 \\ 20,925 & 24,173 \\ 10,555 & 11,865\end{array}$

Percent unemployed

1,865

\section{Housing and crime}

Total Crime Index

70.76

65.91

Percent owner occupied housing

92.8

63.0

Percent vacant housing

7.2

15.9

Median rent

650.00

557.00

\section{Families and children}

Percent female head of household $(\mathrm{HoH}) \quad 24.0 \quad 22.6$

Percent female $(\mathrm{HoH})$ with children $\quad 11.0 \quad 10.9$

Percent population under 5 years age $\quad 5.6 \quad 2.9$

\section{Educational attainment}

Percent with high school diplomas

Percent with Bachelor's or higher

71.1

74.1

$*[7,8]$ references. 
The existence of many pharmaceutical and manufacturing facilities in the Caguas-Humacao Corridor allowed the AMC to become an economic hub for the Central Region of Puerto Rico. However, the closure of US-owned companies due to the elimination of Section 936 federal tax incentives during the 1990s created a rapid economic decline throughout Puerto Rico which impacted AMC and its neighbors. Although the AMC has been working to develop strategies to foster economic development, it continues to be a challenge due to the lack of tax incentives and other programs.

\section{The Caguas' path to sustainability}

In 2009, the AMC received $\$ 400,000$ through two Brownfields grants from EPA to perform environmental assessments on brownfield properties. One of these grants was for hazardous substance and the other for petroleum derivate. The AMC operational areas designated to this initiative included the Planning, Environmental Affairs, and the Traditional Urban Center Development offices. The effort, also included the establishment of a task force to foster the participation of residents and members of the business industry. The main idea behind this effort was to provide a road map to the AMC that allow the development of future efforts to continue with the revitalization of idle or abandoned properties. Early on, the AMC and the EPA recognized the need for a robust and proactive public participation to achieve the revitalization of the identified properties and communities. As the level of coordination and participation among stakeholders and the involvement from the municipal staffers increased the more effective the program became within the identified communities. A regular calendar of meetings was scheduled to maintain a very active group of stakeholders in the Task Force. The AMC also established a yearly calendar of public meetings also available thru their website to present the results from the ongoing activities. Since April 29, 2010; the AMC has organized five public meetings to present the status of the program and the results from each one of the tasks under the grant. Each one of the steps including the property inventory, methodology used to rank them according to the brownfield's standards, the preparation of the Phase I ESA as well as the proposed plans were presented to the community in general. These mechanisms improved the participation of the community throughout the planning process and also helped the local administration to understand the difference between redevelopment and revitalization. The first process has been identified as a top-bottom process while revitalization is a bottom-up process coming from a community-based vision of its needs and aspirations and seeks to build capacity, build partnerships, and mobilize resources to make the vision a reality [9].

Among the first goals identified by Caguas' residents were the need to achieve environmental justice. The communities requested that beside the economic goals of the program, it was important to identify the environmental and social aspects of the proposed redevelopment activities in order to address the needs of the disadvantaged residents of the city. Both the residents and local administrators were conscious in avoiding a pervasive issue generated during the early years of the Brownfields Program, the so called "gentrification". The AMC as well as the 
EPA were aware that a possible outcome of the program was the establishment of a gentrification process due the property market conditions in Puerto Rico. However, the proactive outreach strategies and the public involvement was encouraged by the main partners, the AMC and the EPA. This process was important to establish a relationship with the communities as equal partners in the planning process established early in the program [10].

At the beginning of the program, the public participation was limited probably due to the lack of interest by the local residents or the apprehension to participate in the efforts coming from the government. However, as the program evolved more people became aware of the initiative and joined the effort. As part of the AMC efforts, the communities' boards, created by law was the focal group of this initiative. The communities' boards have 24 members that represent different community levels (residents, businessman, professional and non-profit organization leaders) around the AMC. Property owners were concerned about the potential outcomes in joining the program. This situation was addressed with the support from the EPA that provided reassurance of the benefits to the property owners in joining the initiative. As time passed, more property owners joined the partnership allowing the municipal staffers and the contractor to visit their properties and evaluate them as potential candidates for the inventory.

\section{The economics of the Caguas Brownfields Program}

The Caguas' contractor prepared two inventories since 2010 with over 40 potential brownfield properties, such as abandoned industries, retail shops, restaurants and commercial buildings that may have some level of contamination either by petroleum or hazardous waste.

In the first phase of the Program, we evaluated twenty-five properties. From these properties, only eight were finally submitted to EPA for Phase I ESA approval, six for hazardous substance and two for petroleum derivate. All the Phase I ESAs was fully completed and submitted to EPA. For the second phase of the Program, we evaluated fourteen properties. From these properties, six were finally submitted to EPA for Phase I ESA approval, two for hazardous substance and four for petroleum derivate. Only two have a draft Phase I ESAs. The rest is in process.

The properties were identified with the assistance of personnel from the Environmental Affairs and Planning offices with information provided by local citizens. Each property was visited, photographed, and included on a matrix prepared by EcoStahlia using methods and other related tools prepared by organizations in the United States and Puerto Rico as Malcolm and Pirnie (now ATKINS) Engineers of Puerto Rico. The inventory included basic information like property location, names of current owners, land classification and current use. Most of these properties were not considered because of ownership issues and the fact that many of them are being used partially for housing. The reduction in the number of selected properties under the Brownfield's grant was due to redevelopment potential for each property or ownership related complications. The methodology used provided both the city and the EPA with a detailed picture 
of the existing universe of idle or abandoned properties and the prevalence of issues like Environmental Justice within AMC. After the survey was completed, municipal staffers met with the owners of the properties with the highest opportunities for redevelopment. Some of the owners included local banks, local residents and developers. Once the meetings were completed, the AMC presented the results during the public meetings. A series of End Use Plans were developed as a road map for each property owner to establish a redevelopment strategy under the revitalization plans of the AMC. As of August 31, 2015, three idle properties have been redeveloped. The investment from the private sector has exceeded $\$ 1,200,000.00$ [10].

\subsection{Old Puerto Rico Industrial Development Company (PRIDCO) Parcel}

\subsubsection{History}

The Old PRIDCO Parcel was planned to establish one of the proposed manufacturing facilities sponsored by PRIDCO. As part of the proposed operation, a small sewer pre-treatment plant was built in the property. However, the plant was never used. The equipment was left to rust for more than 30 years.

\subsubsection{Investigation and cleanup}

The old sewer treatment plant was removed from site. No contamination was found at the premises. No clean-up was required.

\subsubsection{Redevelopment}

In 2014, the parcel was purchased by Supermercados Selectos Inc., for their new eastern region distribution center. The project is currently in the design and permitting phases.

\subsubsection{Financial, liability, technical assistance}

The Municipality of Caguas provided the technical assistance thru the Brownfields Program funded by the EPA. No additional financial support was needed for remediation or clean-up activities as the parcel was clean of petroleum or hazardous materials (see figure 4 for a photo of the site).

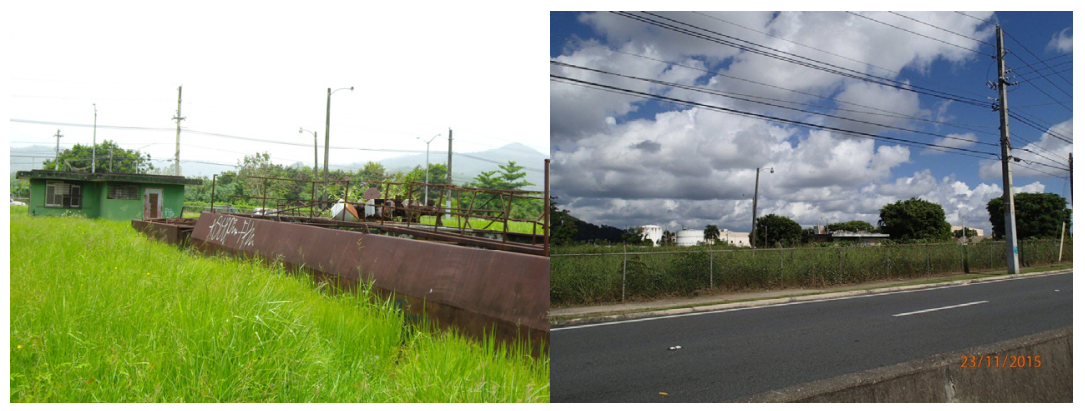

Figure 4: The parcel prior removal of the old sewer treatment plant. 


\subsection{Abandoned building of SEDECO}

\subsubsection{History}

The SEDECO building was used for more than thirty years, first as a circuit breakers and electrical panels distribution center, and after as a furniture store and warehouse. A fire destroyed part of the facility many years ago. The building was included in the Hazardous Materials section of the grant from the EPA.

\subsubsection{Investigation and cleanup}

The building was included in the Hazardous Materials section of the Caguas Brownfield's grant. A Phase I ESA was performed as part of the assessment process but no signs of pollutants were found.

\subsubsection{Redevelopment}

As part of the activities of the program, the AMC discussed with the owner, Banco Santander the results of the study. Using the information obtained from the study, Banco Santander was able to find a new owner; Empresas Borroto. The old building was completely refurbished and now houses a small warehouse, business offices for Claro Phone Company, the Salvation Army's eco-store and a church.

\subsubsection{Financial, liability, technical assistance}

The AMC provided the technical assistance thru the Brownfields Program funded by the EPA. No additional financial support was needed for remediation or cleanup activities as the parcel was clean of petroleum or hazardous materials (see figures 5 and 6 for photos of the site)

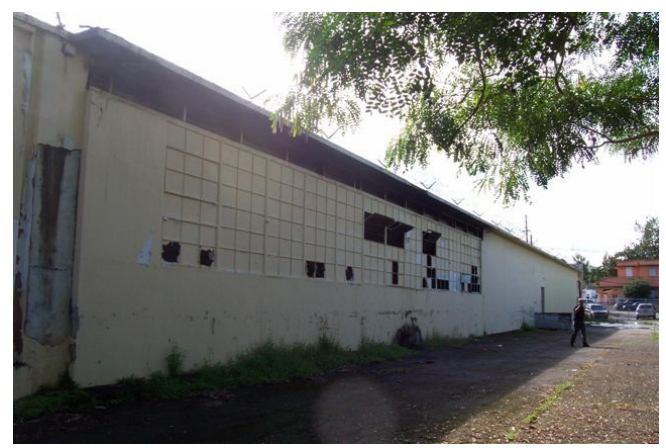

Figure 5: The idle building of SEDECO. 


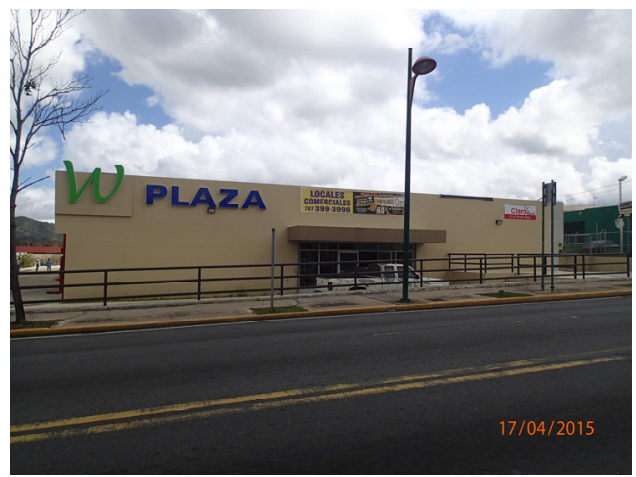

Figure 6: The former SEDECO brownfield after developers cleaned up the property and built new office space, and the warehouse.

\subsection{Idle building of Marianne Store}

\subsubsection{History}

The Marianne building consists of a one-story building, and was previously used as a clothing retail store. Also, according to information obtained from recorded land title records, the property or part of the property was possibly used as a gas station and/or mechanical workshop between the years 1928 through 1962.

\subsubsection{Investigation and cleanup}

Although the study recommends performing a Phase II ESA for the potential presence of petroleum products substances at the site, additional research was done using a local historian and he couldn't find additional data to pursue conducting such a study.

\subsubsection{Redevelopment}

The AMC has decided to establish the new Secretary of Economic Development, including the offices of Tourism, Promo Caguas, Assistance to Small Businesses, Economic Development for ODECUT and Central Oriental Development Bank (BADECO). The 11,495 square feet will house exhibitions, and will serve as a new venue for cultural activities.

\subsubsection{Financial, liability, technical assistance}

The Phase 1 ESA of the redevelopment project will cost approximately $\$ 735,000.00$, including new electrical wiring, restrooms, doors, windows, furniture, water, and roof repairs. The estimated cost of this redevelopment activity is $\$ 1,300,000.00$. Funding will be provided by the municipal government and Community Development Block Grant $(\$ 300,000.00)$. The economic activity will generate 20 construction jobs (see figure 7 for photos of the site). 


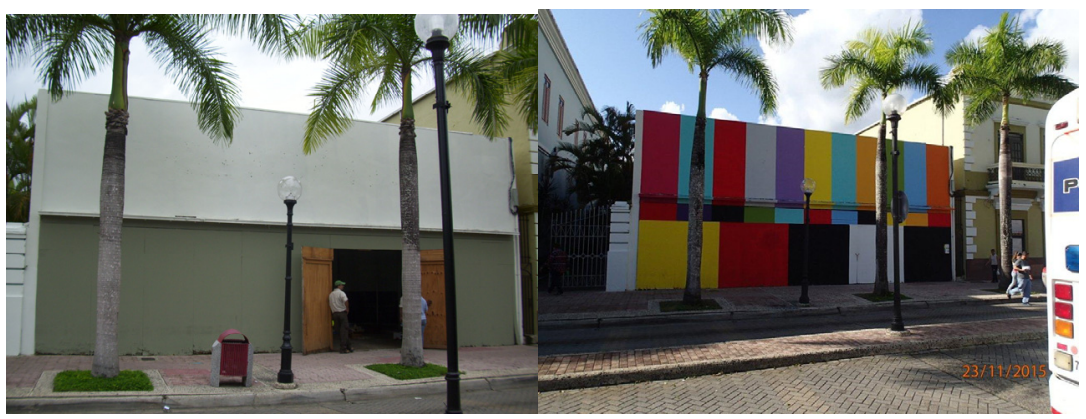

Figure 7: The Marianne Store site.

\section{Conclusions}

Abandoned or idle properties, although a serious problem in Puerto Rico, may represent an excellent opportunity for the economic development of the archipelago. The properties redeveloped in Caguas, Puerto Rico serve as an example on how Brownfields can turn into great tools for sustainability. Thru the process of working with community organizations, the AMC was able to improve the economy of the region while strengthening and maintaining the cultural characteristics of the area. If the stakeholders of the economic development of the Island, state and municipal governments, the developing industry, its residents, and the US regulators continue to get involved and participate in the process from the beginning, the redevelopment of these properties may help in achieving objective, integral and sustainable land management, and consequently in developing local community. There is need for redevelopment and remediation strategies for brownfields while promoting and protecting sustainability of existing communities. Local governments like AMC have a leading role in providing strategies and policies to foster urban sustainable development.

\section{References}

[1] PUERTO RICO: 2010, www.census.gov/prod/cen2010/cph-2-53sp.pdf A Primer for Local Governments on Environmental Liability (www.lgean.org/ documents/primer.pdf).

[2] ARCADIS, B.A.S.E. Methodology for Brownfields.

[3] USEPA, Office of Solid Waste and Emergency Response, Community Engagement Initiative Proposed Action Plan (Draft) (www.epa.gov/oswer/ docs/cei_action_plan_12-09.pdf).

[4] National Governors Association, 2000. Where do we grow from here? New Mission for Brownfields, Attacking Sprawl by Revitalizing Older Communities. Washington, DC.

[5] http://www.oppi.gobierno.pr/Censo_pobl_pr_caract_vivienda_2010.pdf

[6] USEPA, 2012. Assistance Agreement No. TR83492201-1. Brownfields Area Wide Planning Pilot Project. Report on Environmental Site 
Assessment and Future Implementation Existing Conditions and Site Reuse. New York Region 2. 107 pp.

[7] U.S. Census Bureau, 2010 Census of Population and Housing, Population and Housing Unit Counts, CPH-2-53, Puerto Rico U.S. Government Printing Office, Washington, DC, 2012.

[8] Vargas-Ramos, C. (2005). The State of Housing for Hispanics in the United States. Centro de Estudios Puertorriqueños Hunter College. Policy Brief 2(1).

[9] Center for Energy and Environmental Policy, 2014. Brownfields from Redevelopment to Revitalization. Delaware General Assembly and the University of Delaware. Newark, Delaware. 199 pp.

[10] USEPA, 2011. Prepared workbook. Process for Risk Evaluation, Property Analysis and Reuse Decision. New England Region 1 Office. 210 pp. 